Studies in African Linguistics

Volume 33, Number 2, 2004

\title{
ON THE VERBAL SYSTEM IN LANGI \\ A BANTU LANGUAGE OF TANZANIA (F.33)*
}

\author{
Margaret Dunham \\ Université de Paris 3 \& Lacito-CNRS
}

This paper presents the Langi verbal system and the various ways in which tense, aspect and mood are encoded. Through a description of the structures and uses of the various forms, it attempts to demonstrate how the different conjugations fit together to form a coherent whole, morphologically and semantically, and how in some cases the system has been influenced by surrounding Cushitic languages.

\section{Introduction.}

Langi ${ }^{1}$ (Rangi in Swahili) is a Bantu language spoken by approximately 300,000 people in the Kondoa Region of Tanzania. It is of interest linguistically, as its speakers have long been surrounded by non Bantu-speaking communities. In this paper I will show that this has not been without consequences for the language, as evidenced by certain areal features.

* I thank the following for their helpful comments on earlier drafts of this paper: Christiane Paulian, Zlatka Guentchéva, Denis Creissels, Dave Odden and an anonymous reviewer for SAL. I am also indebted to Derek Nurse and Maarten Mous for pointing out (as well as providing) various articles of interest for this study.

1 This language is relatively unknown to linguistics: when I began studying it in 1996, the only published work dated from 1916 (by Otto Dempwolff). The data presented here is all first hand, and was gathered during fieldwork I carried out in Tanzania during my doctoral studies, the funding for which was provided by the LACITO-CNRS. Oliver Stegen of SIL has started working on the language recently; so far he has presented a paper on the vowel system at CALL (Leiden) in 2000, and has published a paper on derivation (2002). A monograph on Langi is in press, see Dunham, in press. 
This paper presents the verbal system of Langi as it is spoken in the towns of Kondoa and Pahi. Through the description of the structures and uses of the various verb forms, I will attempt to demonstrate how the different conjugations fit together to form a coherent whole, morphologically and semantically. I will begin with a brief presentation of the three types of elements which enter into verbal constructions in Langi: verb forms, copulative verbs and infinitival forms. I will then proceed to present the conjugations attested in the language.

1.1. Verb forms. The verb form in Langi, and in Bantu languages in general, is composed of several elements. These elements are not all necessarily present in a given verb form, but always appear in a fixed order. In Langi, a verb form may contain up to seven elements, which can be represented as follows.

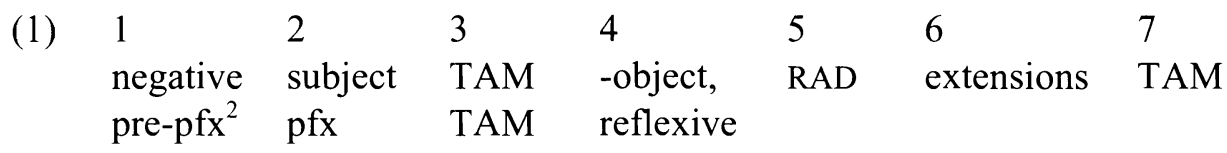

Minimal forms contain only a radical and a suffix. This corresponds to the imperative (see section 2.18 below).

(2)

doma ${ }^{3}$
dəm -a
go -imp2sg

Maximal forms contain seven elements.

${ }^{2}$ Abbreviations used in this paper are as follows. ADV advisory; APPL applicative extension; ASC associative extension; AUX auxiliary; CAUS causative extension; CONN connective; COP copula; DEC decisional; DEICT deictic; DEM demonstrative; DET determinative; DP dependant nominal prefix; HAB habitual; IMP imperative; INF infinitive; INJ injunctive; INV = inevitable; IP independant nominal prefix; lit literally; LOC locative suffix; n/a not applicable; NAR narrative; NEG negative; NEUT neutral extension; OBJ object marker; PASS passive extension; pers.com. personal communication; PFT perfect; PFV perfective; PERS personal pronoun; PFX prefix; PL plural; POSS possessive; P.PFX negation pre-prefix; PRES presentative; PROG progressive; RAD radical; REFL reflexive; REL relator; SFX suffix; SG singular; SP subject prefix; STAT stative extension; SUB subjunctive; TAM tense-aspect-mood marker; $\mathbf{V}$ verb. Numbers in glosses refer to noun classes.

${ }^{3}$ Tones will not be marked on examples. Tonal distinctions in Langi, particularly at the grammatical level, are so restricted that not marking them in this study does not affect the analysis. 
(3) siviiyəvasomera tuku

'They are not reading to them.'

si - va - iys - va - som - $\varepsilon$ r -a tuku

p.pfx - sp2 - prog - obj2 - read -appl -prog neg

Position 1. The first element in the verb form is the negative pre-prefix si. Its presence negates the verb form. Negative forms are generally accompanied by the adverb tuku at the end of the sentence. This is the only negative marker in the verb form, the suffix, for example, never being modified. We will see in sections 2.20 and 2.21 that imperatives and subjunctives are negated in a different manner.

Position 2. The second element in the verb form is the subject prefix. With the exception of imperatives, where the person is marked in the $7^{\text {th }}$ position, a subject prefix in the second position is obligatory. The subject prefixes most frequently encountered in this paper will be the person prefixes. Below is a table showing the prefixes as they appear when followed by a consonant.

$\begin{array}{lll} & \text { Singular } & \text { Plural } \\ 1 & \text { nI- } & \text { tu- } \\ 2 & \text { U- } & \text { mu- } \\ 3 & \text { a- } & \text { va- }\end{array}$

When followed by a vowel, the forms vary somewhat: the prefix vowel either drops (as in example (3) above) or elides, depending on the articulatory nature of the two vowels in contact and also depending on the nature of the following morpheme. In general, when the prefix vowel is altered, the following vowel is lengthened. The rules governing vowel contact may be found in Dunham (forthcoming).

The subject prefix for the $1^{\text {st }}$ person singular has several distinct variants: it is $n I$ - in verb forms, but when prefixed to the copula $-r I$, it is $n d \varepsilon$ - in the affirmative and $n d u$ - in the negative.

(5) nıkad3єnga jumba

'I built a house.'

$$
\begin{aligned}
& \text { nI } \quad-k a-d z \varepsilon n g-a \quad j-u m b a \\
& \text { sp1sg -nar -build -nar ip9-house }
\end{aligned}
$$


(6) nderı muhindza, sinduri mutavana tuku 'I'm a girl, I'm not a boy.'
nde $\quad$-rI mu -hindza
si $\quad$-ndu - -rI
mu -tavana tuku
splsg -cop ipl -girl
p.pfx -splsg -cop
ipl -boy neg

The subject prefix for the $3^{\text {rd }}$ person singular is $a$ - ( $\varnothing$ before a vowel) in all cases except preceding the habitual marker -ว- where it is $y$-.
akadzenga jumba
a $\quad-k a-d z \varepsilon y g-a \quad j \quad-u m b a$
spl -nar -build -nar ip9 -house

'He built a house.'

(8) yosdoma ndżrii

'He goes on the path.'

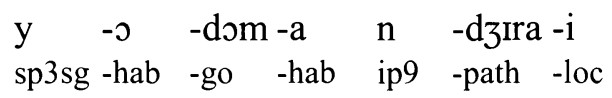

Position 3. The third position contains tense-aspect-mood markers. These will be largely discussed in the following sections. In brief, conjugations in the verb forms are determined by the elements present in the third and the seventh positions (in the case of the imperative and the subjunctive, by a null marker in the $3^{\text {rd }}$ position). In example (5) above, one can see that I have given the same gloss (nar) to the elements found in what corresponds to the $3^{\text {rd }}$ and $7^{\text {th }}$ positions of the verb form. In the representation of the verb form (at the beginning of this section), there are two sets of elements appearing in the $3^{\text {rd }}$ position as one TAM marker, since to may combine with other TAM markers in this position. This phenomenon will be discussed below, in section 2.8 .

Position 4. This position contains object and reflexive markers. Object marking is relatively limited in Langi, and is mostly, but not exclusively, reserved for beneficiaries. See for example (3), (38), (39), (81). The reflexive marker $-i-$, roughly speaking, indicates that the situation applies to the subjects themselves, and is widely encountered in Langi. See for example (20), (21), (74), (104).

Position 5. This position contains the verb radical. The most common structure in Langi is -CVC-, however many other structures are encountered, such as -VC-, -VCVC-, etc.

Position 6. This position contains extensions, which modify the valency of the verb. The most common are the applicative (3), (20), the passive (102), (106) and the causative (45). Several extensions may be present in a given verb form (20), (106). 
Position 7. This position also contains tense-aspect-mood markers, which, in combination with those in the third position, determine the conjugation of the verb form. These will be described in detail below.

1.2 Other predicative elements. The other elements which enter into Langi conjugations, alone or as part of verbal constructions, are the copulas -rI and -id $3 a$ on one hand, and infinitival forms on the other hand. In this section I will present them as they are used independently, and in section 2 we will see how they enter into verbal constructions.

The copula -rI. The copula - $r$ always carries a subject prefix, and in certain cases is inflected for the perfect aspect. On its own, not in a verbal construction, it serves as predicative center with certain nominal determiners, certain types of spatial localizations, etc. In this case it is negated in the same manner as verb forms, i.e. with the pre-prefix $s i$-.

(9) ygo Irr ykondo siirr bi tuku

'The dress is red, it isn't grey.'

$\begin{array}{llllllllll}\text { y } & \text {-go } & \text { I } & \text {-rT } & \text { pkondo } & \text { si } & \text {-I } & \text {-ri } & \text { bi } & \text { tuku } \\ \text { ip9 } & \text {-dress } & \text { sp9 } & \text {-cop } & \text { red } & \text { p.pfx } & \text {-sp9 } & \text {-cop } & \text { grey } & \text { neg }\end{array}$

When the copula is followed by the connective $n a$ it denotes possession. In this case, when negated, the copula is replaced by the negative copula -si.

(10) twaarı na mpesa

'We had money.'

tu $\quad$-a $\quad$-ri $\quad$ na $\quad m \quad-p \varepsilon s a$

splpl -pft -cop conn ip10 -money

(11) twaasi na mpesa tuku

'We didn't have any money.'

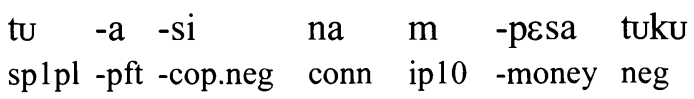

In verbal constructions, we shall see that $-r I$ combines with infinitives and with inflected verbs.

The past copula -idza. -idza is a past tense copula. It always bears a subject prefix. On its own, it denotes a durative (as opposed to a punctual) situation in the past. 
(12) twiidza vimmbi

'We used to be singers.'

$\begin{array}{llll}\text { tu } & - \text { idza } & \text { va }- \text { Imb } & -i \\ \text { splpl } & - \text { cop } & \text { ip2 }- \text { sing } & \text {-sfx }\end{array}$

(13) kwiidza kitfaka aha ndzi vi 'There used to be woods just right here.'

ku -idza ki - t $\int a k a$ aha ndzi vi

sp17 -cop ip7 -woods dem16 deict only

(14) sikwiidza kit $\int a k a$ tuku

'There didn't used to be woods.'

si $\quad-k u \quad-i d z a \quad k i \quad-t \int a k a$ tuku

p.pfx - -sp17 -cop ip7 -woods neg

In verbal compounds, $-i d z a$ combines with inflected verbs. In some cases, it bears the pre-stem aspect marker $-a$ - (see sections 2.16 and 2.18).

1.3 Infinitival forms. The infinitival forms found in verbal constructions show two structures, either $R A D-a$ or $k U-R A D-a$, where $k U$ - is the class 15 prefix which marks all verbo-nominal forms of verbs. The choice between the form with or without the class 15 prefix is based upon how closely bonded, semantically, the two verbal elements are. In Hadermann (1996: 159), it is mentioned that in the languages under study the infinitive sometimes lacks a prefix. She attributes this to morphological factors (whether or not the radical is vowel initial), but says the conditioning may also depend on the syntactic status of the verbo-nominal form within the utterance.

In Langi the difference is independent of the radical initial, and is fully distinctive. For example, there are two future tenses (which will be examined in detail in section 2.19), distinguished by the presence or absence of the class 15 prefix.

(15) sakaata turI 'We are about to hunt.'

sakaat -a to - ri

hunt $\quad$-sfx splpl -cop

(16) kusakaata turt 'We will hunt.' (At some indeterminate future time.)

ku -sakaat -a tu -ri

ip15 -hunt -sfx splpl -cop 
In (15) the form corresponds to an immediate future, something that is about to happen, and in (16) the form corresponds to an indeterminate future.

The same structural distinction is found for example when the infinitival form functions as direct object.

(17) vossaka vina 'They always want to dance / they adore dancing.'

$$
\begin{aligned}
& \text { va }-0 \quad-s a k-a \text { vin }-a \\
& \text { sp2pl -hab -want -hab dance -sfx }
\end{aligned}
$$

(18) vossaka kuvina 'They want to dance.'

$$
\begin{array}{lllllll}
\text { va } & -\mathrm{o} & \text {-sak } & -\mathrm{a} & \mathrm{ku} & - \text {-vin } & -\mathrm{a} \\
\text { sp2pl } & \text {-hab } & \text {-want } & \text {-hab } & \text { ip15 } & \text {-dance } & \text {-sfx }
\end{array}
$$

In example (17), wanting to dance is part of the subjects' personality, a permanent feature, whereas in (18) it is a passing fancy. We will see more examples of this phenomenon in section 2.10 .

Now that we have had a look at the different elements involved, let us turn to the conjugations in which they are used.

\section{Conjugations}

Table 1 is a list of the conjugations which I have observed in Langi. Where applicable, negative forms are indicated by the pre-prefix in parentheses ( $s i$-) or, where the pre-prefix does not apply, by the independent form following the affirmative form(s) to which it applies.

It can be seen from this list that the Langi verbal system, like that of most Niger-Congo languages (Welmers 1973: 344), makes use of both 'simple' verb forms and verbal constructions. Several features however are atypical in comparison to Proto-Bantu or even to most East African Bantu languages. The most striking is the future formation /infinitive + auxiliary/ which runs counter to Greenberg's prediction (1966: 84) that languages where the usual word order is verb-object (VO) also tend to show the the word order /auxiliary + infinitive/. 


\section{Table 1: Langi Verb Conjugations}

\begin{tabular}{|c|c|c|}
\hline Form & Value & Abbreviation $^{4}$ \\
\hline (si-)sp-iyo-RAD-a & Progressive & prog \\
\hline (si-)sp-o-RAD-a & Habitual & hab \\
\hline (si-)sp-a-RAD-a & Perfect & $\mathrm{pft}$ \\
\hline (si-)sp-a-RAD-ire & Perfective & $\mathrm{pfv}$ \\
\hline (si-)sp-a sp-a-RAD-a & Anterior perfect & $\mathrm{pft} \mathrm{pft}$ \\
\hline (si-)sp-a sp-a-RAD-ire & Anterior perfective & pfv pfv \\
\hline sp-endo-RAD-a & Inevitable & inv \\
\hline sp-to-RAD-a & Decisional & $\operatorname{dec}$ \\
\hline (si-)sp-ka-RAD-a ${ }^{5}$ & Narrative & nar \\
\hline sp-rr (ku-)RAD-a ${ }^{6}$ & Narrative present & $\mathrm{n} / \mathrm{a}$ \\
\hline ku-RAD-a sp-a-rז & Narrative past progressive & $\mathrm{n} / \mathrm{a}$ \\
\hline sp-a-ri sp-iyo-RAD-a & Dynamic past progressive & $\mathrm{n} / \mathrm{a}$ \\
\hline sp-a-rr sp-o-RAD-a & Dynamic past habitual & $\mathrm{n} / \mathrm{a}$ \\
\hline (si-)sp-idza sp-o-RAD-a & Stative past habitual & $\mathrm{n} / \mathrm{a}$ \\
\hline sp-idza sp-a-RAD-a & Stative past perfect & $\mathrm{n} / \mathrm{a}$ \\
\hline sp-idza sp-a-RAD-a & Stative far past perfect & $\mathrm{n} / \mathrm{a}$ \\
\hline sp-a-idza (si-)sp-a-RAD-irع & Stative past perfective & $\mathrm{n} / \mathrm{a}$ \\
\hline (si-)sp-a-idza sp-a-RAD-ir $\varepsilon$ & Stative far past perfective & $\mathrm{n} / \mathrm{a}$ \\
\hline (ku)-RAD-a sp-rt & Future & $\mathrm{n} / \mathrm{a}$ \\
\hline si-sp-rt RAD-a & Negative future & $\mathrm{n} / \mathrm{a}$ \\
\hline RAD-a & Imperative $2 \mathrm{sg}$ & imp2sg \\
\hline RAD- $\varepsilon$ & Imperative $1 \mathrm{pl}$ & implpl \\
\hline RAD-i & Imperative $2 \mathrm{pl}$ & imp2pl \\
\hline sp-RAD- $\varepsilon$ & Subjunctive & sub \\
\hline sp-ka-RAD-a & Advisory & $\operatorname{adv}$ \\
\hline sp-ka-RAD- $\varepsilon$ & Injunctive & inj \\
\hline $\begin{array}{l}\text { apa ku-RAD-a / } \\
\text { ku-RAD-a tuku }\end{array}$ & Negative imperative & $\mathrm{n} / \mathrm{a}$ \\
\hline
\end{tabular}

${ }^{4}$ In compound forms, each component has its specific abbreviation (such as cop for 'copula').

${ }^{5}$ This form is identical to the Advisory. They are only distinguished by the context in which they are used (narratives vs. direct speech), and not for example by tone: the tones are identical.

${ }^{6}$ On the presence vs. absence of $k U-$, see the discussion of examples (15) through (18) above. 
However, Langi is not alone in presenting such atypical word order. It is also found in several other Bantu languages, such as Mbugwe (F.34, Mous 2000, 2004), Gusii (E.42, Whiteley 1960), Kuria (E.43, Whiteley, 1955), and a number of languages from the zones B.40-B.50 and H.10-H.30 (Hadermann, 1996).

It is highly probable that the counter-universal structures in Langi were calqued on surrounding Southern Cushitic languages, the most likely candidates being Burunge and Alagwa (Mous, pers. com.). Further indication of influence from these languages is the fact that there are no clear distinctions between degrees of past in Langi. ${ }^{7}$ We will see in the following paragraphs that many conjugations can only incidentally be interpreted as past tenses, and that in most cases, the past is indicated by a distinct copula, which precedes the verb form. This situation is contrary to what is found in most Bantu languages (although comparable to what is found in Standard Swahili, Nurse 2000a: 249), as well as in Proto-Bantu, but closely resembles Southern Cushitic where aspectual distinctions are much more central than temporal ones (Nurse 2000b: 524). Furthermore, the only clear temporal distinctions are expressed in verbal constructions, whereas most aspectual and modal distinctions are expressed directly in the verb form.

2.1 Progressive: (si-)sp-iyo-RAD-a. The progressive indicates a process which is on-going at the time of speech. It is often used to signify that one is in the middle of doing something, and therefore unable to respond to a demand.

(19) niiysluusika

'I'm talking'

$$
\begin{array}{lllll}
\text { nI } & \text {-iys } & \text {-luus } & -\mathrm{Ik} & -\mathrm{a} \\
\mathrm{sp} 1 \mathrm{sg} & \text {-prog } & \text {-talk } & \text {-neut } & \text {-prog }
\end{array}
$$

(20) siiyoseya kintu tuku, iiyəkirrrkana

'He isn't saying anything, he's thinking.'

$$
\begin{aligned}
& \text { si } \quad-a \quad-i y s-s \varepsilon y-a \quad k i \quad-n t u \text { tuku } \\
& \text { p.pfx -sp1 -prog -say -prog ip7 -thing neg }
\end{aligned}
$$

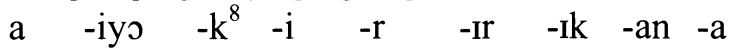

$$
\begin{aligned}
& \text { sp1 } \quad \text {-prog } \quad-k \quad \text {-refl } \quad \text {-think } \quad \text {-appl } \quad \text {-neut-asc } \quad \text {-prog }
\end{aligned}
$$

${ }^{7}$ Or at least in the dialect spoken in the towns of Kondoa and Pahi. I have been told by Nurse that Stegen has found several distinct pasts, however, as Stegen's aim is to establish a 'panLangi' orthography, he has not distinguished between the various dialects.

${ }^{8}$ This consonant is inserted to avoid the merging of the two vowels. It is not part of the reflexive or the radical, the form in the infinitive is kwiirrrıkana 'to think'. 
(21) vasinga siviiyokivaa tuku, viiyobwita 'The children aren't fighting, they're playing.'

$$
\begin{aligned}
& \text { va -singa si -va -iys }-\mathrm{k}-\mathrm{i} \text {-va -a tuku va -iys -bwit -a } \\
& \text { ip2 -child p.pfx -sp2 -prog -k -refl -hit -prog neg sp2 -prog -play -prog }
\end{aligned}
$$

The progressive is never used with stative verbs. For a state current at the time of speech, either the habitual, the perfect or the perfective is used. For example the verb kəofa 'to be afraid' is usually conjugated in the habitual (nэokıวa ndzoka 'I am afraid of snakes / I fear snakes'), whereas the verb kuviha 'to be bad' is usually conjugated in the perfect (naaviha 'I am bad').

2.2 Habitual: (si-)sp-o-RAD-a. The habitual is mostly used to describe situations that are characteristic of an extended period of time, to express recurrent events, statements of general truth. It is used for example to describe what one does in life, but, contrary to the progressive, does not stress that something is on-going at the time of speech.

The habitual shares many features with the perfect (see below), the difference being that the habitual does not refer to an earlier situation, and is mostly used with dynamic verbs, whereas the perfect is commonly used with both dynamic and stative verbs.

(22) noorima

'I farm / I'm a farmer.'

$$
\begin{array}{llll}
\text { nI } & -0 & \text {-rrm } & \text {-a } \\
\text { sp1sg } & \text {-hab } & \text {-farm } & \text {-hab }
\end{array}
$$

(23) nt Jungula yoorya ndzuu

'The hare eats beans.'

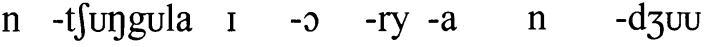

$$
\begin{aligned}
& \text { ip9-hare } \quad \text { sp9 -hab -eat -hab ip10 -beans }
\end{aligned}
$$

(24) sinootereka tuku

'I don't cook/ I'm not the one who cooks in our house.'

si $\quad-n I \quad-0 \quad-t \varepsilon r \quad-\varepsilon k \quad-a \quad t u k u$

p.pfx -splsg -hab -cook -neut -hab neg 
(25) sivostema lukwi tuku

'They are not cutting wood.'

si $\quad-v a \quad-o \quad-t \varepsilon m-a \quad l u \quad-k w i$ tuku

p.pfx -sp2 -hab -cut -hab ip11 -wood neg

In the following example, a stative verb usually inflected in the perfective is inflected in the habitual, to show sarcasm.

tostanga

'We know/we are knowing (we're not stupid).'

tu $\quad-o \quad-\operatorname{tang}-\mathrm{a}$

splpl -hab -know -hab

2.3 Perfect: (si-)sp-a-RAD-a. This form is certainly the reflex of the (tentative) Proto-Bantu 'preterite ipf.' (-á-...-a) (Meeussen 1967: 109), however, as its values are closer to what Comrie calls the perfect (Comrie 1976: 52-65), I have chosen the label which will have meaning for the largest number of readers.

The interpretation of the perfect is linked to the type of verb: stative vs. dynamic. When used with stative verbs, the time reference is the present, as in:

(27) vitfings vyaaboha

'The beads are beautiful.'

$$
\begin{array}{llllll}
\text { vi } & \text {-t } \int i n g o & \text { vi } & \text {-a } & \text {-boh } & -\mathrm{a} \\
\text { ip8 } & \text {-bead } & \mathrm{sp} 8 & \text {-pft } & \text {-be.beautiful } & -\mathrm{pft}
\end{array}
$$

(28) aya madzi siyaahola tuku

'This water is not cold.'

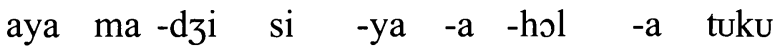

dem6 ip6 -water p.pfx -sp6 -pft -be.cold -pft neg

When used with dynamic verbs, the perfect refers to a present situation which results from a preceding process, the latter having produced a state which is either still current or the effects of which are still felt.

(29) mwaana aakula

'The child has grown.' (One deduces that he used to be short.)

mu -ana a $\quad-a \quad-k u l \quad-a$

ip1 -child sp1 -pft -grow -pft 
(30) naadoma kaayii yaavs

'I have been to their house (already, therefore I don't want to go back).'

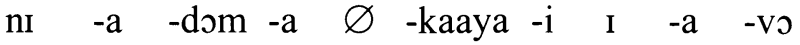

sp1sg -pft -go $\quad$-pft ip9 - house $\quad$-loc dp9 - det - poss3pl

(31) sinaadoma kaayii yaavo tuku

'I haven't been to their house (but would like to go).'

$\begin{array}{llllllllllll}\text { si } & -n I & -a & -d o m & -a & \varnothing & -k a a y a & -i & \text { I } & -a & -v \jmath & \text { tuku }\end{array}$

p.pfx -splsg -pft $\quad$-go $\quad$-pft ip9 - house $\quad$-loc dp9 - det - poss3pl neg

2.4 Perfective: (si-)sp-a-RAD-ire. This conjugation can also be traced back to Proto-Bantu, however it is not clear whether it is the reflex of Meeussen's 'recent pf.' (-a-, -lídé) or his 'pret. pf.' (-á-, -lídé) (Meeussen 1967: 113), in neither case

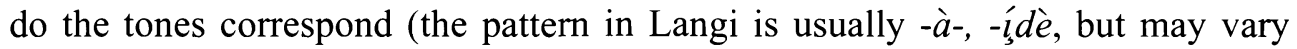
according to context).

The perfective denotes a completed situation. Contrary to the perfect, it does not refer to a past situation.

(32) mwaana aakurire

'The child grew.'

mu -ana a $-\mathrm{a} \quad-\mathrm{kul}^{9} \quad-\mathrm{ir} \varepsilon$

ip1 -child sp1 -pfv -grow -pfv

(33) kuri sidzaalumire musungaati tuku

'The dogs didn't bite the rich man.'

$\varnothing \quad$-kuri si $\quad$-dzi -a -lum -ire mu -sungaati tuku

ip10 -dog p.pfx -sp10 -pfv -bite -pfv ip1 -rich.man neg

The perfective can be used with all types of past adverbs, 'yesterday' as well as 'last year'.

(34) idzo, naadomire na ludzii

'Yesterday I went to the watering hole.'

$\begin{array}{lllllllll}\text { idzo } & \text { nI } & \text {-a } & \text {-dom } & \text {-ire } & \text { na } & \text { lu } & - \text { dzi } & -i \\ \text { yesterday } & \text { sp1sg } & \text {-pfv } & \text {-go } & \text {-pfv } & \text { conn } & \text { ip11 } & \text {-watering.hole } & \text {-loc }\end{array}$

${ }^{9} / 1 /$ is pronounced $[\mathrm{r}]$ before $/ \mathrm{i} /$. 


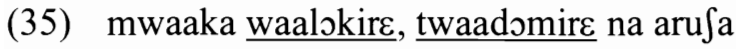

'Last year, we went to Arusha.'

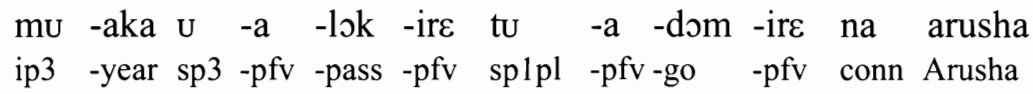

One could be tempted to consider the perfective a 'past tense'. In my opinion, however, the emphasis is on the completed aspect rather than on the fact that it is past. This is supported by the use of the perfective in conditional phrases.

(36) koni naadomire kaayii, rya nderı

'If I go home, I will eat.' (lit. 'If I went home, I will eat'.)

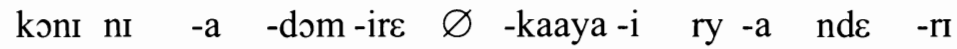

if $\quad$ splsg -pfv -go - pfv ip9 -house - loc eat -sfx splsg -cop

2.5 Anterior perfect: (si-)sp-a sp-a-RAD-a. The anterior perfect has the same aspectual values as the perfect but refers to a situation which takes place prior to another situation, which is necessarily in the past. The structure of this form is unusual, as in Bantu verb forms a TAM marker must be prefixed to a radical, not to another TAM marker. According to my informants, the verb is simply "doubled".

(37) fatuma aa aatumama hantu ali uudzire

'Fatuma was working when Ally came.'

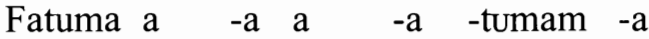

Fatuma sp3sg -pft sp3sg -pft -work -pft

$\begin{array}{llllll}\text { ha } & - \text { ntu } & \text { Ally a } & \text {-a } & \text {-ud3 } & \text {-ire } \\ \text { ip16 } & \text {-place } & \text { Ally } & \text { sp3sg } & \text {-pfv } & \text {-come }-p f v\end{array}$

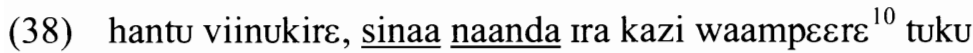

'When they left, I hadn't started the work you gave me.'

${ }^{10}$ This form is imbricated. Imbrication affects verbs inflected in the perfective, generally those bearing certain extensions, where, roughly speaking, the extension and the suffix merge. The outcome varies both according to the extension and to the radical final consonant. Other examples can be found in (41), (70), (71). For more information on imbrication, see Bastin (1983) and Dunham (forthcoming). 


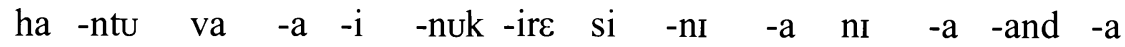
ip16-place sp2pl -pfv-refl -leave-pfv p.pfx -sp1sg -pft sp1sg -pft -begin -pft

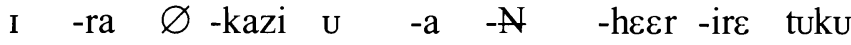

$$
\begin{aligned}
& \text { dp9 -dem ip9-work sp2sg -pfv -obj1sg -give -pfv neg }
\end{aligned}
$$

(39) hayi vaarı ava vasinga? sinaa naavoona tuku

'Where were the children? I hadn't seen them.'

hayi va -a -ri ava va -singa

where sp2 -pft -cop dem2 ip2 -child

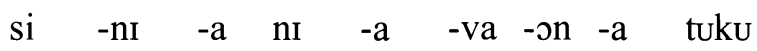

p.pfx -splsg -pft sp1sg -pft $\quad$-obj2 -see $\quad$-pft neg

A possible explanation is that these structures, as well as those presented in the following section, at one point contained an auxiliary which has since been deleted.

2.6 Anterior perfective: (si-)sp-a sp-a-RAD-irc. The anterior perfective has the same aspectual values as the perfective but, as for the anterior perfect in the preceding section, refers to a situation which takes place prior to another, past situation.

(40) hantu twaa twaaturire ma ali akaloka

'When we appeared, then Ally left (lit. passed).'

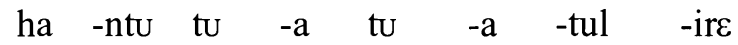

ip16 -place splpl -pfv splpl -pfv -appear -pfv

ma ali a $\quad-k a \quad-l o k-a$

then Ally sp3sg -nar -pass -nar

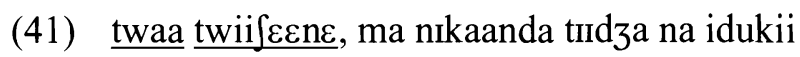

'We had met, then (after which) I started running off to the store.'

$\begin{array}{llllllll}\text { tu } & -\mathrm{a} & \mathrm{tu} & -\mathrm{a} & -\mathrm{i} & -\int \mathrm{i} & -\mathrm{an} & -\mathrm{ir \varepsilon} \\ \text { splpl } & -\mathrm{pfv} & \mathrm{splpl} & -\mathrm{pfv} & - \text { refl } & - \text { meet } & -\mathrm{rec} & -\mathrm{pfv}\end{array}$

ma nI $-\mathrm{ka}$-and -a - tIId3 -a na $\mathrm{i}$-duki $-\mathrm{i}$ then sp1sg -nar -start -nar -run -sfx conn ip5-store -loc 
2.7 Inevitable: sp-endo-RAD-a. Verbs in this conjugation refer to a situation which the speaker considers will happen in the near future and which is inevita-

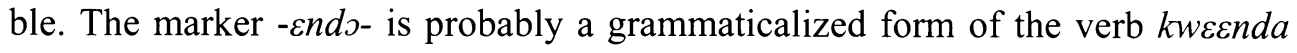
'want, love'. This is quite frequent in Bantu languages, to the point that Heine (1997: 2) includes it in his catalogue of probabilistic predictions that can be made about African languages: "(v) If a language develops a future tense marker then most likely it will use either of the motion verbs 'go (to)' or 'come (to)' or a verb of volition "want'.".

As will be seen from the following examples, Langi has retained the notion of volition, but in the sense that when something 'wants' to do something, it means that that something is bound to happen. This type of value is found for example in Moore (Raphael Kaboré, pers. com.), a Gur language spoken in Burkina Faso, where when one says 'it wants to rain', it means that the clouds are so full that it is bound to rain, or 'the glass wants to fall' meaning that if the glass is not moved it will fall from the table.

(42) mpaka mnenya tundopata habari

'All the way to Mnenya we are bound to get the news.'

mpaka mnenya tu $-\varepsilon$ ndo - pat - a $\quad \varnothing \quad$-habari

until Mnenya splpl -inv -get - sfx ipl0 -news

(43) ma ha mpitfi yecndokwatwa

'Then, here, the hyena is going to get caught.'

ma ha m -pitfi I $-\varepsilon n d o-k w a t \quad-w \quad-a$

then here ip9 -hyena sp9 -inv -touch -pass - -sfx

(44) kintu mundorya ni waarı

'What you are going to eat is porridge.' (Whether you like it or not.)

kI -ntu mu $-\varepsilon n d s^{11}-r y-a \quad n I \quad U \quad$-arI

ip7 -thing sp2pl -inv -eat -sfx pres ip14 -porridge

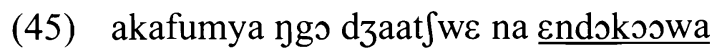

'She took off her clothes (in order) to wash.'

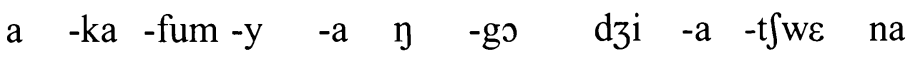

${ }^{11}$ Preceeded by the vowel /U/, the marker's initial/E/ drops. 
sp1 -nar -exit -caus -nar ip10 -clothes dp10 -det -poss3sg conn

$\begin{array}{lllll}\text { a } & -\varepsilon n d o & -k & -o w & -a \\ \text { spl } & - \text { inv } & -k & \text {-wash } & - \text { sf } x\end{array}$

2.8 Decisional: sp-to-RAD-a. It is highly probable that - $t$ - is a grammaticalized form of a full verb (Güldemann 2003: 185), as is the case for -Endo-. Contrary to - $\varepsilon n d s$ - however, it is difficult to say which full verb it stems from. Languageinternally, the only likely source is kutsola 'take'. I have been unable to find any examples of other Bantu languages where 'take' has been grammaticalized, however the phenomenon is widely attested in the languages of the world (Hagège 1975, Sebba 1987, Li and Thompson 1974, Lord 1993, Ozanne-Rivierre 2004). Contrary to what is found in Langi, in most of the cases described, the verb 'take' is serialized and tends to undergo a gradual reanalysis as a preposition or a case marker. The one example I have found that is somewhat similar to Langi is in the Polynesian Outlier language, Pileni. According to Åshild Næss (2004: 242), two constructions use the verb toa 'take', with different semantic and syntactic properties: one where toa introduces an object argument, and another where it contributes a volitional or inceptive meaning to the clause, similar to the English 'to take to V-ing'.

One other possibility is that the form derives from a verb 'to leave' or 'to go' (in Langi kU-tamanya and kU-doma respectively) followed by an infinitive. Botne (1999: 484) mentions two Bantu languages where a marker -to- is found. In the first case it is derived from 'to leave, to go', in to-kos-e 'va prendre' (Ntomba C.66: Gilliard 1928), and in the second case (Lozi S.34: Gorman 1950) it is derived from 'come' $+k u$-inf: $m u$-to-ng- $a$ 'come $(\mathrm{Pl})$ and get (it)'. Hadermann (1999: 454-455) mentions one case where a marker -too- is found, and also posits its origins in a verb 'to go': "En nkengo (C.61), une des formes du futur comporte la marque -too- qui pourrait refléter une séquence ancienne-ta-ko- où -ta- remonterait à un verbe 'aller'."

In the examples I have found in Langi, the use of -to- signifies that the speaker is about to/has decided to/intends to undertake an action voluntarily.

(46) aakwiire, tutosongola mayiti yaat $\int w \varepsilon$

'He is dead, we are going to remove his corpse.'

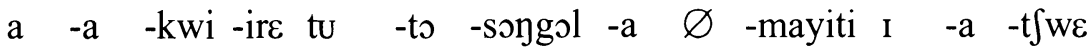

spl -pfv -die -pfv splpl -dec -remove -sfx ip9 -corpse dp9 -det -poss3sg 
(47) jkukulume Itoveka vi, keyi kakatosla

'Just when the rooster was about to crow, he (small bird) took (clothes).'

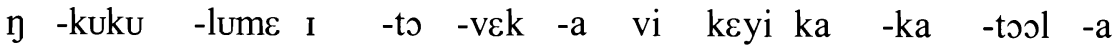
ip9-chicken -male sp9 -dec -crow -sfx just then sp12 -nar -take -nar

A particularity of the decisional marker is that it can follow other TAM markers in the $3^{\text {rd }}$ position of the verb form, for example, the following:

Habitual + Decisional. When the decisional is combined with the habitual marker, the speaker indicates that a decision has been taken, and that it is in the process of being carried out.

(48) nootokoowa ludzii

'I'm going to wash in the watering hole.' (Despite contrary orders.)

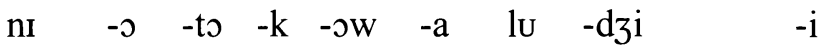

sp1sg -hab -dec -k -wash -hab ip11 -watering.hole -loc

Perfect + Decisional. Here the speaker indicates that a decision was taken, and has already been carried out:

(49) naatsksowa

'I still went and took a bath.'

nI $\quad-a \quad-t o \quad-k \quad-o w-a$

splsg $\quad$-pft $\quad-$ dec $\quad-k \quad-$ wash $-p f t$

Progressive + Decisional. Here, too, the use of the marker -to- seems to add a level of intention or decision to the basic verb, but, as the form is in the negative, to indicate that the decision is not in the process of being carried out.

(50) mbula yəovaa, ava vadala siviiystormma tuku

'It's raining, the women are not going to farm.'

$$
\begin{array}{lllllllllll}
\text { m } & \text {-bula } & \text { I } & \text {-o } & \text {-va } & \text {-a } & & & & & \\
\text { ip9 } & \text {-rain } & \text { sp9 } & \text {-hab } & \text {-beat } & \text {-hab } & & & & & \\
& \text { ava } & \text { va } & \text {-dala } & \text { si } & \text {-va } & \text {-iys } & \text {-to } & \text {-rim } & \text {-a } & \text { tuku } \\
\text { dem2 } & \text { ip2 } & \text {-woman } & \text { p.pfx } & \text {-sp2 } & \text {-prog } & \text {-dec } & \text {-farm } & \text {-prog } & \text { neg }
\end{array}
$$

Inevitable + Decisional. When -Endo- and -to- are combined, the resulting values are inevitability and intention/decision. 
(51) no ut fiku yecndotorya ndzuv 'It's at night (that) he goes and eats beans.' (Even though he knows he's bound to be caught).

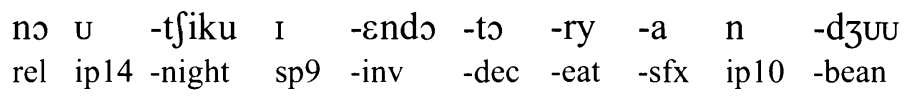

(52) hapana kundotokowa

'Do not go and wash anyway.' (Despite our orders).

hapana ku $-\varepsilon$ ndo $\quad-$ to $\quad-k \quad-\jmath$ w $\quad-a$

neg ip15 -inv -dec $-\mathrm{k}$-wash - sfx

From these examples it can be seen that the inevitable -endo- and the decisional -to-, show rather atypical behavior. This leads me to hypothesize that they entered the Langi tense/aspect/mood system more recently than the other markers we have seen thus far, such as the anterior or the progressive, for example.

The first distinctive feature of -to- and - $\varepsilon n d s-$ is that the corresponding full lexical verbs are still in common use (with reservations however concerning the origins of -to-, see above).

(53) toola idihwa

'Take some white sorghum.'

$$
\begin{array}{llll}
\text { tool } & \text {-a } & \text { i } & \text {-dihwa } \\
\text { take } & \text {-imp2sg } & \text { ip5 } & \text {-sorghum }
\end{array}
$$

(54) simba kıntu yecnda nı mahonge 'The lion, what he loves is steak.'

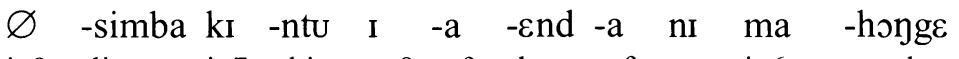

ip9 -lion ip7 -thing sp9 -pft -love -pft pres ip6 -steak

I would further hypothesize that - $t$ - was grammaticalized before - $\varepsilon n d s-$ as the latter, in its full form, is still attested as the first verb in a verb combination. For example.

(55) mpitfi dzeعnda kusakaata 'Hyenas love to hunt.'

$\begin{array}{lllllllll}\text { m } & \text {-pitfi } & \text { dzi } & \text {-a } & -\varepsilon n d & -a & \text { ku } & \text {-sakaat } & \text {-a } \\ \text { ip10 } & \text {-hyena } & \text { sp10 } & \text {-pft } & \text {-love } & \text {-pft } & \text { ip15 } & \text {-hunt } & \text {-sfx }\end{array}$


Furthermore, to can combine with other markers in the $3^{\text {rd }}$ column. In my opinion, the value common to these two verbs, kweEnda 'want, love' and kutsola 'take' which led to their grammaticalization, and which was lacking in the Langi verb system, is that of showing the speaker's involvement, or attitude towards the state of affairs expressed in the clause. This type of 'attitude' marker is described by Maarten Mous for Ma'a (2003: 116, 129, 131). A further similarity between the markers mentioned by Mous and the Langi - $t$ - - is their possibility of combining with other pre-radical TAM markers.

2.9 Narrative: (si-)sp-ka-RAD-a. This conjugation is identical in structure to what I have dubbed the 'advisory' (see below, section 2.22). A similar state of affairs was attested by Meeussen (1967), who mentions three distinct conjugations with - $k a$ - (motional, inceptive and subsecutive) and notes (p. 109): "The relationship between $-k a ́-,-k a$ - and an often attested near homophone formative with meaning 'and (he did...)' (subsecutive) is not clear.'

In Langi, the narrative and the advisory are never used in the same speech context: the narrative, as its name indicates, is only used in narration, whereas the advisory, and the injunctive (with the suffix $-\varepsilon$ ) is always addressed to someone, even if the advice concerns a third person.

The narrative is never used as the first verb form in a text, the time frame always having been previously established, either by the traditional introduction aho kale 'Once upon a time...' or by a preceding verb form. Once the time frame is established, successive events are presented in the narrative, most often separated by $m a$ 'then'.

(56) ma akadoma na ludzii

'Then she went to the watering hole.'

ma a $\quad-k a \quad-d o m-a \quad$ na lu $\quad-d z i \quad-i$

then sp1 -nar -go -nar conn ip11 -water -loc

(57) ma kawuluka na dzira jgo

'Then it flew away with those clothes.'

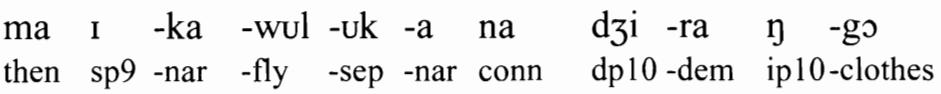

Verbs inflected in the narrative are usually translated by a preterit in English, but in Langi it cannot be considered a 'past tense', as by itself it carries no reference to time, and is dependant on a separate form. In this respect, the narrative is com- 
parable to the 'aorist' described by Guentchéva (1990: 107) for Bulgarian, and Robert (1996) for Wolof. Robert states:

L'Aoriste est une forme verbale qui n'indique pas de repérage temporel. (...) Les événements à l'Aoriste n'ont pas par eux-mêmes ni lieu ni temps; ils s'inscrivent dans un cadre situationnel prédéfini à l'aide d'une autre conjugaison. [p. 377]

2.10 Narrative present: sp-rı (kU-)RAD-a. In this construction, the verb radical following the copula may or may not carry the infinitive prefix $k U$-, depending on how closely, semantically, the subject is bound to the lexical verb. In example (58), the lion is coming of his own free will - he could choose not to - thus the verb carries the infinitive prefix. In example (59), the hare is struggling to get by and can do nothing about it, thus the prefix is absent. See also examples (15)-(18).

This conjugation is only attested in narratives. It is used when there is a break in the narration, either in time or in space.

(58) haha simba IrI kuudza no Jiana mpitfi

'Now the lion is coming to meet the hyena.'

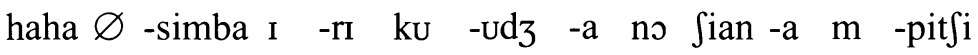

now ip9-lion sp9-cop ip15 -come -sfx rel meet -sfx ip9 -hyena

This example is taken from a story. ${ }^{12}$ The preceding sentences present the lion and the hyena, and the narrative present is then used to signify that the speaker has finished the introduction and is entering the narrative present.

(59) nt fungula ir kweta 'The hare is struggling (to get by).'

$\begin{array}{llllll}\text { n } & \text {-t } \int \text { ungula } & \text { I } & - \text { rI } & \text { kwet } & -\mathrm{a} \\ \text { ip9 } & \text {-hare } & \text { sp9-cop } & \text { struggle } & - \text {-sf } x\end{array}$

Here too, the hare has been introduced as part of the story in the preceding sentences, example (59) serving to describe the state the hare is in, in the narrative present.

\footnotetext{
${ }^{12}$ This story and others may be read and listened to on the LACITO Archive Project website: http://lacito.vjf.cnrs.fr/archivage.
} 
2.11 Narrative past progressive: kU-RAD-a sp-a-rı. Unfortunately I have only one example of this construction in my data, and it is elicited, ${ }^{13}$ but it is also mentioned in Nurse (2003: 97). There is further mention of this same construction, in this order (infinitive + copula) as well as in the inverse order (copula + infinitive) in Mous (2000: 475, however his examples were given by Nurse). ${ }^{14}$ According to Mous, the change in word order is probably due to emphasis (pers. com).

(60) kuscka twaarı ma uhu maka akaanda rra

'We were laughing then this guy started to cry!'

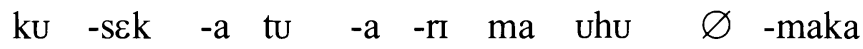

ip15 -laugh -sfx splpl -pft -cop then dem1 ipla-guy

$\begin{array}{llllll}\text { a } & -k a & \text {-and } & -\mathrm{a} & \text { rir } & -\mathrm{a} \\ \mathrm{spl} & \text {-nar } & \text {-start } & \text {-nar } & \text { cry } & -\mathrm{sfx}\end{array}$

Despite the scarcity of data, I have given this example as it shows a counteruniversal word order (infinitive + copula) - see the general introduction to section 2).

2.12 Dynamic past progressive: sp-a-rI sp-iyo-RAD-a. This structure is also only attested in elicitation, in one example. However, it confirms that the copula $-r I$ is largely productive in verbal constructions, both with and without the perfect marker, and both preceding and following the lexical verb.

(61) twaar twiiyoscka 'We were (in the process of) laughing.'

$\begin{array}{lllllll}\text { tu } & -\mathrm{a} & -\mathrm{rI} & \mathrm{tu} & -\mathrm{iyo} & -\mathrm{s} \varepsilon \mathrm{k} & -\mathrm{a} \\ \mathrm{splpl} & -\mathrm{pft} & -\mathrm{cop} & \mathrm{splpl} & - \text { prog } & - \text { laugh } & \text {-prog }\end{array}$

\subsection{Dynamic past habitual: sp-a-ri sp---RAD-a.}

(62) twaari tooscka

'We were laughing.'

$\begin{array}{lllllll}\text { tu } & -\mathrm{a} & -\mathrm{rI} & \mathrm{tu} & -\mathrm{c} & -\mathrm{s} \varepsilon \mathrm{k} & -\mathrm{a} \\ \mathrm{spl} 1 \mathrm{pl} & -\mathrm{pft} & -\mathrm{cop} & \mathrm{splpl} & - \text { hab } & \text {-laugh } & - \text { hab }\end{array}$

\footnotetext{
${ }^{13}$ It must be noted that this is a common problem when one works on a language that has not been previously described.

${ }^{14}$ There seems to be some confusion in the translation in Mous ('We are buying'), which should read as it appears in Nurse (2003) 'We were laughing'.
} 
From examples (60)-(62), it seems that the copula inflected in the perfect situates a process in the past. We will see in the following sections that when the lexical verb is stative, as opposed to dynamic, the copula -idz $a$ is used.

2.14 Stative past habitual: (si-)sp-idza sp-o-RAD-a. This construction is made up of a verb inflected in the habitual preceded by the copula -id $3 a$, which serves to place the situation in the past. The aspectual values of the main verb are kept.

(63) twiidza tookımba hantu tooyenda, haha tootidza

'We used to sing while walking, now we run.'

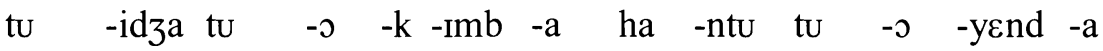
splpl -cop splpl -hab -k -sing -hab ip16 -place splpl -hab -walk -hab

haha tu -0 -tIId 3 -a

now splpl -hab -run -hab

(64) twiidza tookikala Kondoa ma tukasaama na London

'We used to live in Kondoa, then we migrated to London.'

$\begin{array}{clllllll}\text { tu } & - \text { idza } & \text { tu } & -0 & -k & -i k a l & -a & \text { Kondoa } \\ \text { splpl } & - \text { cop } & \text { splpl } & \text {-hab } & -\mathrm{k} & \text {-reside } & \text {-hab } & \text { Kondoa } \\ \text { ma } & \text { tu } & \text {-ka } & - \text { saam } & - \text { a } & \text { na } & \text { London } \\ \text { then } & \text { splpl } & \text {-nar } & \text {-migrate } & \text {-nar } & \text { conn } & \text { London }\end{array}$

(65) hantu noskikaala amerikani ${ }^{15}$ siniidza nostumama benkii tuku 'When I lived in America I didn't use to work in a bank.'

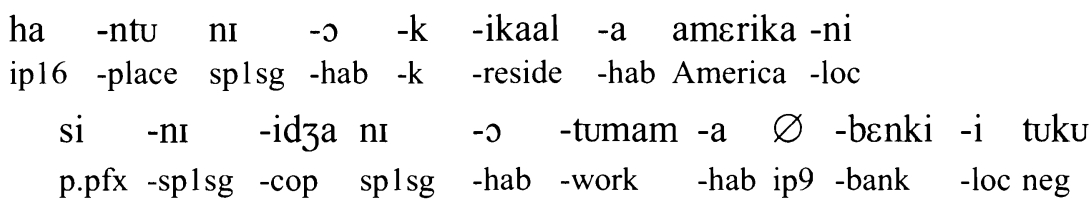

2.15 Stative past perfect: sp-idza sp-a-RAD-a. In this construction the copula is combined with verbs inflected in the perfect aspect. The latter keeps its aspectual values, but is placed in the past.

${ }^{15}$ This locative suffix is borrowed from Swahili. 
(66) niidza neعnda tIIdza na tfuuri 'I used to like to run in the morning.'

$$
\begin{array}{lllllllllll}
\mathrm{nI} & -\mathrm{idza} & \mathrm{nI} & -\mathrm{a} & -\varepsilon n d & -\mathrm{a} & \mathrm{tIId} 3 & \text {-a } & \text { na } & \mathrm{kI} & \text {-uri } \\
\mathrm{sp1sg} & -\mathrm{cop} & \text { splsg } & \text {-pft } & - \text { love } & \text {-pft } & \text { run } & \text {-sfx } & \text { conn ip7 } & \text {-morning }
\end{array}
$$

(67) mwaasu wiidza waavarka 'When the sun was shining.'

(in response to: 'When did you usually eat?')

$$
\begin{array}{lllllllll}
\text { mu } & \text {-asu } & \text { U } & - \text { idza } & \text { u } & \text {-a } & \text {-var } & \text {-Ik } & \text {-a } \\
\text { ip3 } & \text {-sun } & \text { sp3 } & \text {-cop } & \text { sp3 } & \text {-pft } & \text {-shine } & \text {-neut } & \text {-pft }
\end{array}
$$

(68) Ira siku iidza yaaboha 'That day was beautiful.'

$$
\begin{array}{lllllllll}
\text { Ira } & \varnothing & \text {-siku } & \text { I } & \text {-idza } & \text { I } & \text {-a } & \text {-boh } & \text {-a } \\
\text { dem9 } & \text { ip9 } & \text {-day } & \text { sp9 } & \text {-cop } & \text { sp9 } & \text {-pft } & \text {-be.beautiful } & \text {-pft }
\end{array}
$$

2.16 Stative far past perfect: sp-a-idza sp-a-RAD-a. This is one of the rare cases where one finds distinctions between degrees of pasts in Langi. The only other case is shown below (section 2.17 vs. 2.18 ). Unfortunately I have only one example of this conjugation, and no examples where this conjugation is in the negative.

(69) woskati naadza mududi, naadza naadudya sana

'When I was small, I was very small.'

$\begin{array}{lllllll}\text { U } & \text {-okati } & \text { nI } & \text {-a } & \text {-idza } & \text { mu } & \text {-dudi } \\ \text { ip14 } & \text {-moment } & \text { splsg } & \text {-pft } & \text {-cop } & \text { dp1 } & \text {-small }\end{array}$

$\begin{array}{llllllll}\mathrm{nI} & -\mathrm{a} & -\mathrm{d} z a & \mathrm{nI} & -\mathrm{a} & - \text { dudi } & -\mathrm{a} & \text { sana } \\ \text { sp1sg } & -\mathrm{pft} & -\mathrm{cop} & \text { sp1sg } & -\mathrm{pft} & - \text { be.small } & -\mathrm{pft} & \text { very }\end{array}$

2.17 Stative past perfective: sp-idza (si-)sp-a-RAD-ire. Verbs in the stative past perfective refer to situations which were current in the past.

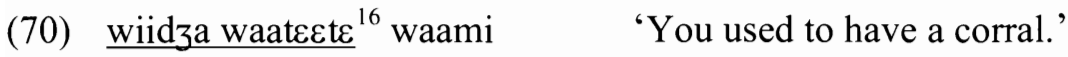

$\begin{array}{llllllll}\text { U } & - \text { idza } & \text { U } & -a & -t \varepsilon t & -i r \varepsilon & \text { U } & \text {-ami } \\ \text { sp2sg } & - \text { cop } & \text { sp2sg } & \text {-pfv } & \text {-have } & \text {-pfv } & \text { ip14 } & \text {-corral }\end{array}$

\footnotetext{
${ }^{16}$ This verb is defective, appearing only in the perfective, where it shows an irregular form of imbrication. A comparable verb for 'have' is found in Chaga (M.-L. Montlahuc, pers. com.), where it is also defective (although to a lesser extent than in Langi).
} 


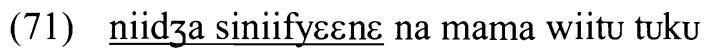

'I used to not look like our ${ }^{17}$ mother.'

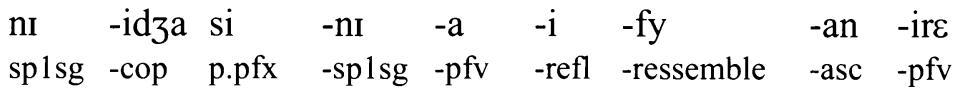

na $\varnothing \quad$-mama u $\quad$-a $\quad-$ itu tuku

conn ipla -mother dp1 -det -poss1pl neg

We shall see in example (74) below that in the stative far past perfective, it is the copular verb which carries the negative pre-prefix.

\subsection{Stative far past perfective: (si-)sp-a-idza sp-a-RAD-ire.}

(72) vaadza vaatecte udzusi wooruta $^{18}$

'They used to be blacksmiths.' (lit. 'They used to have the profession of pulling.')

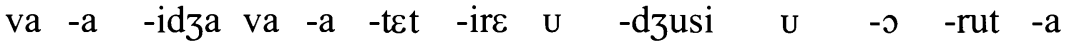

sp2 -pft -cop $\quad$ sp2 -pfv -have -pfv ip14 -profession pp14

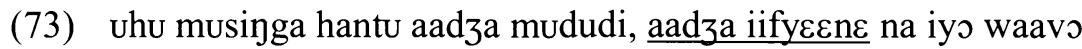

'When this child was small he looked like their mother.'

uhu mu -singa ha -ntu a -a -idza mu -dudi, a -a -idza

dem1 ip1 -child ip16-place sp1-pft -cop dp1 -small sp1 -pft -cop

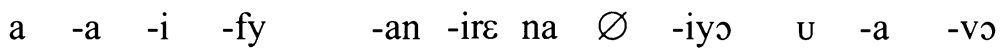

sp1 -pfv -refl -resemble -asc -pfv conn IP1a -mother dp3 -det -poss3pl

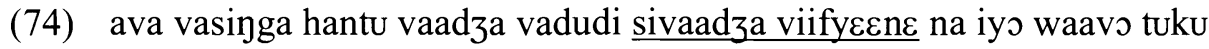
'When these children were small they didn't used to look like their mother.'

ava va -singa ha -ntu va -a - idza va -dudi si - va - a $\quad$-idza dem2 ip2 -child ip16 -place sp2 -pft -cop dp2 -small p.pfx

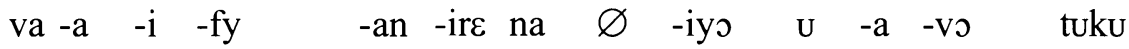
sp2-pfv -refl-ressemble -asc -pfv conn IP1a -mother dp1 -det -poss3pl neg

${ }^{17}$ Family members (and homes) are never possessed in the singular in Langi.

${ }^{18}$ Relative forms apparently share the same TAM markers as the habitual, only the prefix differs (the pronominal prefix is used as opposed to the subject prefix). 
As can be seen from the examples in the preceding five sections, in accordance with its use independently, verb constructions with the past copula always refer to durative as opposed to punctual situations.

2.19 Future: (ku-)RAD-a sp-rı. This form denotes either an immediate or an indeterminate future, depending on the presence of the class 15 prefix $k u$-. I have grouped the two forms together for practical reasons: in several cases, such as in the negative or the interrogative, only one form is possible, so presenting the two forms together eliminates the need to go back and forth between sections.

The prefixless form denotes an immediate future, something that is about to happen.

(75) jeya ari

$$
\begin{array}{llll}
\text { nєy } & -\mathrm{a} & \mathrm{a} & -\mathrm{rI} \\
\text { sleep } & -\mathrm{sfx} & \mathrm{sp1} & -\mathrm{cop}
\end{array}
$$

(76) muti wiya urI

mu -tI wiy -a u - rI

ip3 -tree fall - sfx $\mathrm{sp} 3 \quad$-cop
'He is about to sleep.'

'The tree is about to fall.'

The prefixed form is used to denote an indeterminate future.

(77) mutr kuwiya urI

'The tree will fall (some day).'

$$
\begin{aligned}
& \text { mu -tI } \quad \text { ku } \quad \text {-wiy }-\mathrm{a} \quad \mathrm{u} \quad \text {-ri } \\
& \text { ip3 -tree ip15 -fall }- \text { sfx } \quad \text { sp3 } \quad \text {-cop }
\end{aligned}
$$

The prefixed form is also used whenever a time or place is mentioned.

(78) kukera turi mutı lamutonds ku $-\mathrm{k} \varepsilon \mathrm{r}-\mathrm{a}$ tu $\quad$-ri mu $\quad$-tI lamutondo ip15 -cut -sfx splpl -cop ip3 -tree tomorrow

(79) kudoma arr na dodoma 'He will go to Dodoma.' $\begin{array}{lllllll}\text { ku } & \text {-dom -a } & \text { a } & \text {-rI } & \text { na } & \text { dodoma } \\ \text { ip15 } & \text {-go } & \text {-sfx } & \text { sp1 } & \text {-cop } & \text { conn } & \text { Dodoma }\end{array}$ 
(80) mwaarımu kuvasomera arı vasinga kitabu fulii

'The teacher will read a book to the children at school.'

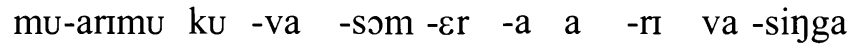

ip1 -teacher ip15-obj2 -read -appl-sfx sp1 -cop ip2 -child

kI $\quad-$ tabu $\varnothing \quad-\int u l \varepsilon \quad-i$

ip7 -book ip9 - school -loc

In conditional phrases, the prefixless form is used in the apodosis, probably to indicate that the action/event/state will immediately follow the fulfillment of the condition.

(81) konı naadomire kaayii, rya nderi 'If I go home, I will eat.'

koni nI -a $\quad$-dom -ire $\varnothing \begin{array}{lllllll}\text {-kaaya } & -\mathrm{i} & \text { ry } & -\mathrm{a} & \mathrm{nd} \varepsilon & \text {-rI }\end{array}$

if sp1 sg -pfv $\quad$-go $\quad$-pfv ip9 - house $\quad$-loc eat - sfx splsg $\quad$-cop

(82) konı wimbire, ni vina nderi 'If you sing, me, I will dance.'

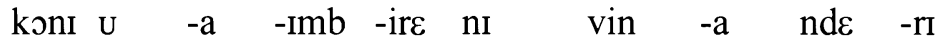

if $\quad$ sp2sg -pfv $\quad$-sing - pfv pers1sg dance $\quad$-sfx splsg $\quad$-cop

However the prefixed form is used when there is an object marker in the verb form, certainly in part because of possible confusion between the object prefix and the infinitive prefix (in the following example, both $k U_{-}^{-}$).

(83) koni wimbire kukuvinira nderi 'If you sing, I will dance for you.'

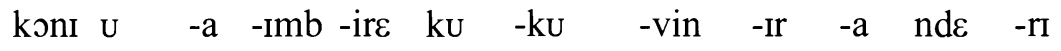

if $\quad$ sp2sg -pfv-sing -pfv ip15 -obj2sg $\quad$-dance $\quad$-appl $\quad$-sfx $\quad$ sp1sg $\quad$-cop

To the best of my knowledge, this constituent order (verb + copula) is limited to a very small number of Bantu languages. Among these languages, I believe a distinction must be made between those which accept SOV order and those with strict SVO order. In the first category are found languages from Guthrie's zones B.40-50 and H.10-H.30. These have been studied by Hadermann (1996) who states: 
La deuxième construction que nous avons analysée est celle où l'infinitif est antéposé à un verbe auxiliant. Dans cette structure l'infinitif est généralement introduit par le préfixe locatif mu- et l'ensemble traduit l'aspect progressif du procès verbal en question. Donc, contrairement à ce qui se passe dans les constructions à verbe redoublé, le morphème locatif (ou sa trace) propre au temps du progressif (cf. la reconstruction $* \mathrm{PV}$-di-mu-NV) n'apparait pas dans la forme verbale conjuguée mais dans la forme nomino-verbale antéposée. Cette caractéristique est un signe du fait que la structure 'infinitif + auxiliant' est issue de la séquence 'auxiliant + infinitif' mais à un moment où celle-ci pouvait encore

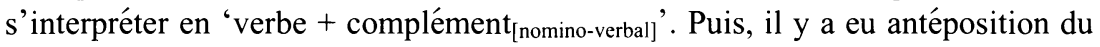
complément, ceci probablement pour des raisons d'emphase. De nouveau, l'existence de l'ordre SOV dans les langues en question a sans doute facilité l'antéposition du locatif infinitival. Au moment où la structure emphatique '(S) Loc-Inf Aux' devient une structure non marquée, un processus de grammaticalisation peut se déclencher et le locatif infinitival sera réinterprété en noyau verbal, suivi d'un verbe-auxiliant 'être'. [p. 167]

The second category are languages with strict SVO order which nevertheless show constructions where the infinitival form precedes the auxiliary. In this category are found for example the closely related Gusii (E.42) and Kuria (E.43). In Gusii, the forms with an auxiliary (the copula -re) following a main verb correspond to what I call a narrative present (Whiteley 1960: 57) (tones not marked).

(84) nkogenda ${ }^{19}$ nde boono korigia embori

'Now I'm going looking for the goat.'

When the auxiliary carries the verbal prefix $-a$-, the form corresponds to what I call a narrative past progressive.

(85) nkorema naare boono ngotimoka nde 'I've been hoeing and now I'm resting'

In Kuria, the forms with an auxiliary following the main verb correspond to something between what I call present progressive and habitual (Whiteley 1955: 92).

${ }^{19}$ The class 15 prefix is $k o-$, these forms almost certainly bear the cliticized focus marker $n(i)$ (Nurse and Muzale 1999). 
(86) ggokora are emeremo kira urusiku 'He's working every day.'

(87) ykorema nde bono ykumunya nde 'I'm hoeing and am resting.'

In Mbugwe (F.34) the situation is slightly different. All the tenses that make use of an auxiliary in combination with an infinitive show the order verb-auxiliary, in other words, the order never varies, contrary to what is found in Gusii, Kuria and Langi. In Mbugwe, three different auxiliaries may follow the main verb: the present progressive -kende, the future -je (which is the verb ja 'come' conjugated in the optative, marked by the suffix $-e$ ) and the habitual -anda (Mous 2000: 471).

(88) 'The rain falls with force.'

mbula $o$-tova e -kende na ngulu

9:rain $\quad 15$-rain 9 -pres.prog with 9:force

(89) 'We will eat cassava.'

$\begin{array}{llll}\text { ora } & \text { ko } & - \text { je } & \text { mohogo } \\ 15: \text { eat } & 1 \mathrm{pl} & \text {-come:sbj } & \text { 3:cassava }\end{array}$

(90) 'Do you eat fish?'

$\begin{array}{llll}\text { ora } & \mathrm{w} & \text {-anda } & \text { nsiye? } \\ 15 \text { :eat } & 2 \mathrm{sg} & \text {-hab } & \text { 9:fish }\end{array}$

One feature shared by Gusii, Kuria, Mbugwe and Langi is that they have long been surrounded by communities speaking non-Bantu languages, where the object precedes the verb (Nurse 2000b: 525-6), which seems to indicate that this phenomenon is areal (Dahl 2001: 1456 who states 'Areal linguistics is traditionally concerned with similarities between geographically contiguous languages, in particular when they cannot be ascribed to a common proto-language.'). Furthermore, the adoption of these structures may well have been facilitated by internal factors. In Langi, the order infinitive + copula is only attested in main clause affirmatives, and in all other cases the order copula + infinitive is found.

(91) nadi un doma 'When will you go?'

$\begin{array}{lllll}\text { nadi } & \mathrm{U} & -\mathrm{rI} & \mathrm{d} \jmath \mathrm{m} & -\mathrm{a} \\ \text { when } & \text { sp2sg } & \text {-cop } & \text { go } & -\mathrm{sfx}\end{array}$


(92) yombe siir nwa madzi yossi tuku 'The cow will not drink all the water.'

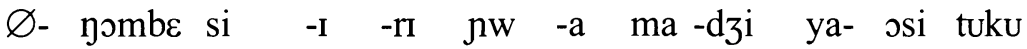

ip9- cow p.pfx -sp9 -cop drink -sfx ip6 -water dp6- all neg

(93) nı mwaarımu no arr soma kitabu

'It is the teacher who will read a book.'

nI mu -arimu no a

pres ipl -teacher rel spl -cop read -sfx ip7 -book

(94) kuudza ant koni art recta t $\mathrm{aakurya}$

'He can come if he brings food.' (lit. 'He will come if he is bringing food.')

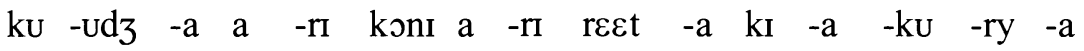
ip15-come -sfx sp1 -cop if sp1-cop bring - -sfx ip7 7 -det -ip15 -eat $\quad$-sfx

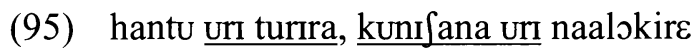

'When you appear, you will find me gone.' (lit. 'When you will appear...')

ha $\quad$-ntu $\quad$ u $\quad$-rI tul $\quad$-Ir $\quad$-a

ip16 -place sp2sg -cop appear -appl -sfx

$\begin{array}{llllllllll}\mathrm{ku} & -\mathrm{nI} & -\mathrm{San} & -\mathrm{a} & \mathrm{u} & -\mathrm{rI} & \mathrm{nI} & -\mathrm{a} & -\mathrm{lok} & -\mathrm{ir} \varepsilon\end{array}$

ip15 -obj1sg -find -sfx sp2sg -cop splsg -pfv -leave -pfv

We also saw that constituent order in Langi can change in other circumstances, namely for reasons of emphasis, such as in example (60).

2.20 Imperatives: RAD-sfx. Imperatives are characterized by the absence of both subject prefixes and pre-radical TAM markers. There are three affirmative imperative forms in Langi, distinguished by their suffixes.
(96) $2 \mathrm{sg}$ doma
'go!'
Imba
'sing!'
dom -a
Imb -a
go -imp2sg
sing -imp2sg

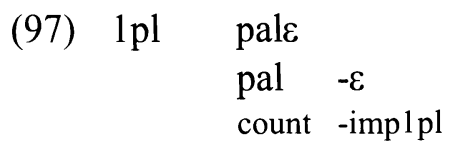
'let's count!'
saire
'let's taste!'
$\begin{array}{lll}\text { sa } & - \text { Ir } & -\varepsilon \\ \text { taste } & - \text { appl } & - \text { implpl }\end{array}$ 
(98) $2 \mathrm{pl}$ reki mburi 'leave the goat!' iti

$$
\begin{aligned}
& \text { rek -i } m \text {-buri it }-i \\
& \text { leave -imp2pl ip9 -goat pour -imp2pl }
\end{aligned}
$$

There are three negative imperative forms, apparently interchangeable: apa $k U$ $R A D-a$, hapana $k U-R A D-a$ or $k U-R A D-a$ tuku. These forms are impersonal, equivalent to the English 'no V-ing' or 'do not V'. They are composed of a verb in the infinitive preceded by either apa or hapana (the latter form is borrowed from Swahili and appears to be replacing the former). The third possible negative form is composed of a verb in the infinitive accompanied by the adverb tuku placed at the end of the sentence.

(99) apa kutIIdza 'No running.'

$$
\begin{array}{llll}
\text { apa } & \text { ku } & \text {-tIId3 } & \text {-a } \\
\text { neg } & \text { ip15 } & \text {-run } & \text {-sfx }
\end{array}
$$

(100) hapana kuyenda ndzrii 'No walking on the path.'

$\begin{array}{lllllll}\text { hapana } & \text { ku } & -\mathrm{y} \varepsilon \text { nd } & -\mathrm{a} & \mathrm{n} & \text {-d } 3 \text { Ira } & -\mathrm{i} \\ \text { neg } & \text { ip15 } & \text {-walk } & \text {-sfx } & \text { ip9 } & \text {-path } & \text {-loc }\end{array}$

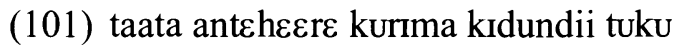

'Papa told me: do not farm in the hills.'

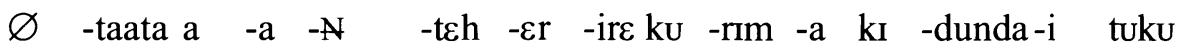
ip1a -father sp1 -pfv -obj1sg -listen -appl -pfvip15-farm -sfx ip7 -hill $\quad$-loc neg

2.21 Subjunctive: sp-RAD- $\varepsilon$. The subjunctive mood is marked by a $\varnothing$ TAM marker in the $3^{\text {rd }}$ position, combined with the suffix $-\varepsilon$. Contrary to the imperative, the verb bears a subject marker in the $2^{\text {nd }}$ position. This mood is used to express wishes, orders, obligations, etc. Whereas the imperative is necessarily addressed to someone, this is not the case for the subjunctive.

(102) uloolwe

$$
\begin{array}{llll}
\text { U } & - \text { lool } & - \text { w } & -\varepsilon \\
\text { sp2sg } & \text {-marry } & \text {-pass } & \text {-sub }
\end{array}
$$

'that you marry/ you should marry/

I want you to get married' 
(103) ad3enge numba 'that he build a house'

a $\quad-d 3 \varepsilon \eta g$

sp1 -build -sub ip9 -house

(104) tiilarre krrume 'that we show each other our magic'

$\begin{array}{lllllll}\text { tu } & -\mathrm{i} & - \text { la } & -\mathrm{Ir} & -\varepsilon & \mathrm{kI} & - \text { rUm } \varepsilon \\ \text { splpl } & \text {-refl } & \text {-show } & \text {-appl } & - \text { sub } & \text { ip7 } & \text {-magic }\end{array}$

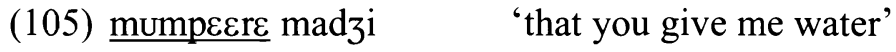

$\begin{array}{llllll}\mathrm{mu} & -\mathrm{N} & -\mathrm{h} \varepsilon \varepsilon \mathrm{r} & -\varepsilon & \mathrm{ma} & -\mathrm{d} z \mathrm{i} \\ \mathrm{sp2pl} & \text {-obj1sg } & \text {-give } & - \text { sub } & \text { ip6 } & \text {-water }\end{array}$

The subjunctive mood does not have its own negative form, and instead shares that of the imperative. Furthermore, many negative subjunctive forms are rendered by verbs with negative meaning, such as kudira 'to not go'.

(106) adiriwe 'that she be made to not go'

$$
\begin{array}{lllll}
\text { a } & - \text { dir } & -\mathrm{i} & -\mathrm{w} & -\varepsilon \\
\text { sp1 } & \text {-not.go } & \text {-caus } & \text {-pass } & \text {-subj }
\end{array}
$$

2.22 Advisory: sp-ka-RAD-a. This form bears what is commonly called a distal marker, $-k a-$, in the $3^{\text {rd }}$ position. This marker is thought to derive from a verb meaning 'go' (see Botne 1999 for a comprehensive study of the marker - $k a$-). In Langi, the distal imparts the notion of movement, even though the direction is not always itive. These forms are used to denote advice or weak orders.

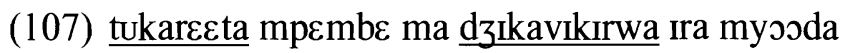

'We must bring horns, and the horns must be filled with potion.'

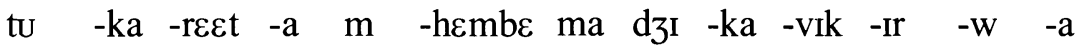

sp1pl -adv -bring -adv ip10 -horn then sp10 -adv -put -appl -pass -adv

I $\quad$-ra mi - oda

dp4 -dem ip4 -potion 
(108) ukatahıra madzi vi, ukuudza na kaayii

'Just go and fetch water, and come back home.'

u $\quad$-ka -tah -Ir -a ma - dzi vi $\quad$ u $\quad-k a \quad-u d z \quad-a$

sp2sg -adv-fetch -appl-adv ip6 -water only sp2sg -adv -come-adv

na $\varnothing \quad$-kaaya $-\mathrm{i}$

conn ip9 -house -loc

(109) vakasakwa vaosi 'Elders must be found.'

va $\quad-k a \quad-s a k-w \quad-a \quad$ va - -osi

sp2 -adv -find -pass -adv ip2 -elder

2.23 Injunctive: sp-ka-RAD-e. Combining the distal marker with the suffix $-\varepsilon$, these forms denote forceful orders. $-k a$ - is the only pre-radical TAM marker attested in combination with the subjunctive suffix $-\varepsilon$.

(110) uka uka ukaloolwe ni mambeya vaa waarı

'Come, come, you must be married to Mambeya vaa Waari.'

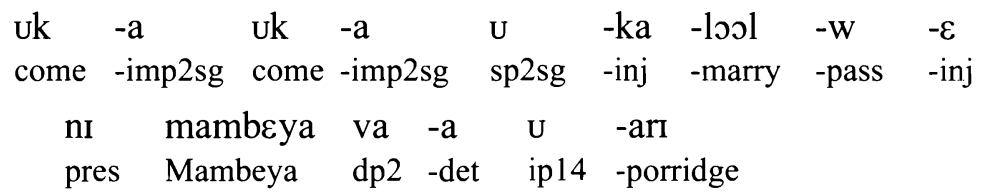

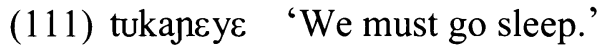

$\begin{array}{llll}\text { tu } & -\mathrm{ka} & -\mathrm{n} \varepsilon \mathrm{y} & -\varepsilon \\ \mathrm{sp} 1 \mathrm{pl} & -\mathrm{inj} & - \text { sleep } & -\mathrm{inj}\end{array}$

\section{Conclusion.}

The Langi verbal system is similar to most Bantu, and indeed Niger-Congo languages in that it expresses tense, aspect and mood through both 'simple' verb forms and syntactic verbal constructions. However, it seems to have adopted certain areal features, which probably originated through contact with the neighboring Cushitic languages, Alagwa and Burunge. Langi also seems to have adopted a new system of distinctions within the verbal paradigm, favoring aspectual oppositions over temporal ones, as evidenced by the fact that temporal distinctions are expressed through verbal constructions, whereas aspectual and modal distinctions 
are expressed directly by morphological verb form. Langi thus contributes to the study of how language contact, or perhaps more importantly, language enclavement, can lead to the adoption of grammatical elements, and even to a change in word order.

\section{REFERENCES}

Bastin, Yvonne. 1983. La finale verbale -ide et l'imbrication en bantou. Tervuren: Musée Royal de l'Afrique Centrale.

Botne, Robert. 1999. "Future and distal -ka-'s: Proto-Bantu or nascent form(s)?". Bantu Historical Linguistics, ed. by Jean-Marie Hombert \& Larry M. Hyman. Stanford, CA: CSLI. Pp. 473-515.

Comrie, Bernard. 1976. Aspect: an Introduction to the Study of Verbal Aspect and Related Problems. Cambridge: Cambridge University Press.

Dahl, Östen. 2001. "Principles of areal typology". Language Typology and Language Universals, ed. by Martin Haspelmath, Ekkehard König, Wulf Oesterreicher \& Wolfgang Raible. vol 2. Berlin \& New York: Walter de Gruyter. Pp. 1456-1470.

Dempwolff, Otto. 1916. "Beiträge zur Kenntnis der Sprachen in DeutschOstafrika - 8. Irangi”, Zeitschrift für Kolonialsprachen 6: 102-23.

Dunham, Margaret. Forthcoming. Eléments de description du langi, langue bantu F33 de Tanzanie. Louvain-Paris: Peeters.

Gilliard, L. 1928. Grammaire synthétique de lontomba. Bruxelles: Editions de l'Essorial.

Gorman, W. A. R. 1950. Simple Silozi: A Guide for Beginners. London: Longmans Green and Co. 
Greenberg, Joseph H. 1966. "Some universals of grammar with particular reference to the order of meaningful elements". Universals of Language, ed. by Joseph Greenberg. Cambridge, MA: M.I.T. Press. Pp. 73-113.

Guentchéva, Zlatka. 1990. Temps et aspect : l'exemple du bulgare contemporain. Sciences du langage. Paris: CNRS.

Güldemann, Tom. 2003. "Grammaticalization". The Bantu Languages, ed. by Derek Nurse and Gérard Philippson. London: Routledge. Pp. 182-194.

Hadermann, Pascale. 1996. "Grammaticalisation de la structure Infinitif + Verbe $_{\text {conjugué }}$ dans quelques langues bantoues". Studies in African Linguistics, 25: 155-169.

Hadermann, Pascale. 1999. "Les formes nomino-verbales de classes 5 et 15 dans les langues bantoues du Nord-Ouest". Bantu Historical Linguistics, ed. by Jean-Marie Hombert \& Larry M. Hyman. Stanford, CA: CSLI. Pp. 431-472.

Hagège, Claude. 1975. Le problème linguistique des prépositions et la solution chinoise. Louvain: Editions Peeters.

Heine, Bernd. 1997. "Grammaticalization theory and its relevance for African linguistics". African Linguistics at the Crossroads: Papers from Kwaluseni, $1^{\text {st }}$ World Congress of African Linguistics, Swaziland, ed. by Robert K. Herbert. Köln: Rüdiger Köppe Verlag. Pp. 1-16.

Li, Charles N. \& Thompson, Sandra A. 1974. "Coverbs in Mandarin Chinese: verbs or prepositions?". Journal of Chinese Linguistics 2: 257-278.

Lord, Carol. 1993. Historical Change in Serial Verb Constructions. Amsterdam: John Benjamins.

Meeussen, Achiel Emiel. 1967. "Bantu grammatical reconstructions". Africana Linguistica III. MRAC Annales 61. Tervuren. Pp. 79-121.

Mous, Maarten. 2000. "Counter-universal rise of infinitive-auxiliary order in Mbugwe (Tanzania, Bantu F 34)". 'Mehr als nur Worte...', ed. by Rainer 
Vossen, Angelika Mietzner \& Antje Meissner. Köln: Rüdiger Köppe Verlag. Pp. 469-481.

Mous, Maarten. 2003. The Making of a Mixed Language: The case of Ma'a / Mbugu. Amsterdam: John Benjamins.

Mous, Maarten. 2004. A Grammatical Sketch of Mbugwe, Bantu F34, Tanzania. Köln: Rüdiger Köppe Verlag.

Næss, Åshild. 2004. "Serial verbs and complex constructions in Pileni”. Complex Predicates in Oceanic Languages: Studies in the Dynamics of Binding and Boundness, ed. by Isabelle Bril \& Françoise Ozanne-Rivierre. Berlin: Mouton de Gruyter. Pp. 225-249.

Nurse, Derek \& Muzale, Henry R. T. 1999. 'Tense and aspect in Great Lakes Bantu languages'. Bantu Historical Linguistics, ed. by Jean-Marie Hombert \& Larry M. Hyman. Stanford, CA: CSLI. Pp. 517-544.

Nurse, Derek. 2000a. Inheritance, Contact, and Change in Two East African Languages. Köln: Rüdiger Köppe Verlag.

Nurse, Derek. 2000b. "Diachronic Morphosyntactic Change in Western Tanzania'. 'Mehr als nur Worte...', ed. by Rainer Vossen, Angelika Mietzner \& Antje Meissner. Köln: Rüdiger Köppe Verlag. Pp. 517-534.

Nurse, Derek. 2003. 'Aspect and tense in Bantu languages'. The Bantu Languages, ed. by Derek Nurse and Gérard Philippson. London: Routledge. Pp. 90-102.

Ozanne-Rivierre, Françoise. 2004. 'The evolution of the verb 'take' in New Caledonian languages'. Complex Predicates in Oceanic languages: Studies in the Dynamics of Binding and Boundness, ed. by Isabelle Bril \& Françoise Ozanne-Rivierre. Berlin: Mouton de Gruyter. Pp. 331-346.

Robert, Stéphane. 1996. 'Aspect zéro et dépendance situationnelle: L'exemple du Wolof'. Dépendance et intégration syntaxique: Subordination, coordination, connexion, ed. by Claude Müller. Tübingen: Niemeyer. Pp. 153-161. 
Sebba, Mark. 1987. The Syntax of Serial Verbs: An Investigation into Serialization in Sranan and Other Languages. Amsterdam: John Benjamins.

Stegen, Oliver. 2000. "Rangi vowel system: five or seven?" Paper presented at the 30th Colloquium of African Languages and Linguistics, Leiden, August 28-30, 2000.

Stegen, Oliver. 2002, "Derivational processes in Rangi". Studies in African Linguistics 31: 129-153.

Welmers, William E. 1973. African Language Structures. Berkeley: University of California Press.

Whiteley, Wilfred Howell. 1955. The Structure of the Kuria Verbal and its Position in the Sentence. London: Ph.D. dissertation.

Whiteley, Wilfred Howell. 1960. The Tense System of Gusii. Kampala: East African Institute of Social Research.

34 Bd. de l'Hôpital

75005 Paris, France

madunham@club-internet.fr
[Received July 7, 2004, accepted January 6, 2005] 